HELMINTHOLOGIA, 58, 3: 263 - 270, 2021

\title{
Endohelminth fauna of teleost fishes from coasts of Şile region of the Black sea
}

\author{
B. ASLAN ÇELIK'1,*, M. C. OĞUZ² \\ ${ }^{1 *}$ Department of Parasitology, Faculty of Veterinary Medicine, Siirt University, Siirt, Turkey, https://orcid.org/0000-0002-0130-970X, \\ E-mail: burcakaslan@siirt.edu.tr, ${ }^{2}$ Department of Medical Services and Techniques, Vocational Health College of Mardin Artuklu \\ University, Mardin, Turkey, https://orcid.org/0000-0001-8729-1389
}

Article info

Received October 19, 2020

Accepted March 10, 2021

\section{Summary}

A total of 508 fish specimens belonging to 19 species collected in the coast of Şile region of the Black sea were examined to detect the presence of endohelminths. Of this, $357(70.27 \%)$ were found to be infected with parasites. 15 distinct helminths species were recovered including four species of nematodes, seven digenean species, one species of cestodes and three species of acanthocephalans. It was also determined that the species of nematode Hysterothylacium aduncum was the most common parasite and the most diverse endohelminth fauna was found in Gobius niger and Solea vulgaris, with five species. Furthermore, it should be noted that Capillaria gracilis is reported for the first time from the Turkish coasts. The infection rates, hosts, and parasites are listed in this paper.

Keywords: Acanthocephala; Cestoda; Digenea; Nematoda;Teleosts; Şile

\section{Introduction}

Fish are aquaculture resources with a significant economic value, and present essential nutrients amongst the foods of animal origin (Öztürk, 2005). Fish constantly live amongst parasites in the waters of their natural environment (Taşçi \& Topçu, 1990). These parasites not only reduce the nutritional value of the fish, but also hamper their growth, reproduction, and feeding capabilities (Özan \& Kır, 2005). While the majority of the parasites involved with fish present no danger to humans, it is also known that the ones harmful for humans tend to have more than one development stage (Adams et al., 1997). Aquatic environments are continuously exposed to different types of waste materials, and such pollution is known to cause an increase in the prevalence of diseases and anomalies encountered in fish populations (Turgut \& Özgül, 2009). Since the pollution in these environments is most often of chemical nature, the fish and other animals that act as hosts for the parasites are weakened and lose immune resistance, which in turn causes gaps in the ecological nutritional chain (Oğuz, 1996). The fact that researches focused on fish diseases has gained increased attention and importance in recent years also makes it necessary to gain more insight into the parasitic fauna of fish (Demirtaş, 2011).

This study was, therefore, performed to determine the endohelminth fauna of the fish caught from the coastal areas of the Şile region of the Black Sea.

\section{Materials and Methods}

\section{The Study Area}

This study was performed between February 2010 and December 2013 in the Şile district of İstanbul province. Şile (Fig.1) is located towards the northwest of the country, along the northeast edges of the Marmara Region, facing the Black Sea coasts of the Kocaeli Peninsula. The Black Sea is a semi-closed inland sea with an average depth of $1300 \mathrm{~m}$ and a total surface area of $420.000 \mathrm{~km}^{2}$. The Black Sea is also the world's largest anoxic sea, with an oxy-

\footnotetext{
* - corresponding author
} 
genated upper layer of approximately 100 - 150 meter depth, while the lower layers are anoxic and contains hydrogen sulfide (Güngör \& Çağatay, 2010).

\section{Fish Material and Sample collection}

The fishers of the coasts of Sile usually hunt shoreline fish. A total of 508 fish distributed over 19 species was obtained from these fishers between February 2010 and December 2013. Fish were collected either alive or as fresh dead and transported to the land inside canisters filled with seawater. The dissections of the fish were performed in the port of Şile, and one specimen from each species was reserved to perform species identification. Fish species were identified using the guidelines established by Slastenenko (1955), Geldiay (1969), and Can \& Bilecenoğlu (2005). Mid-caudal lengths of the fish were measured and recorded, and the interior organs of the fish were removed by inserting a thinpoint scissor into the anus and cutting towards the anterior of the fish body. To make it easier to identify any parasitic presence, the specimens were placed into a petri dish containing physiological saline. The parasites were first searched macroscopically within the body cavity and in interior organs, and any visible parasites were collected into watch-glass using pasteur pipettes to be preserved in physiological saline.
The digestive tracts of the fish were cut from the stomach to the intestines. The contents of the intestines were investigated, and the intestinal epithelium was scraped to search for the presence of any parasites. Livers were cut into small pieces, which were then grounded for microscopic evaluation. Air and gall bladders of the fish were punctured and searched for any parasites. The samples were evaluated under a binocular stereomicroscope, and any nematodes detected were collected into plastic tubes containing $70 \%$ alcohol. The number and location of the parasites within the body were recorded along with the date, the fish species, and the parasite type and count in a sticker used as a label for the tubes, which were then stored until the slides were prepared. Other parasites, meanwhile, were placed between slide glasses and fixed using the A.F.A (Acetic acid + formaldehyde + alcohol) solution, then kept in jars containing $70 \%$ alcohol until their permanent slides were prepared.

The permanent slides of the nematodes were prepared by placing them between the glass and cover slides and covering them with glycerine-gelatine. For the other parasite groups, the permanent mounts were prepared as suggested by Baylis (1922), Wardle (1932), Pantin (1960), Cable (1976), Bylund et al. (1980), and Pritchard \& Kruse (1982). Parasite species were identified through the guidelines of Dawes (1947), Yorke \& Maplestone (1962),

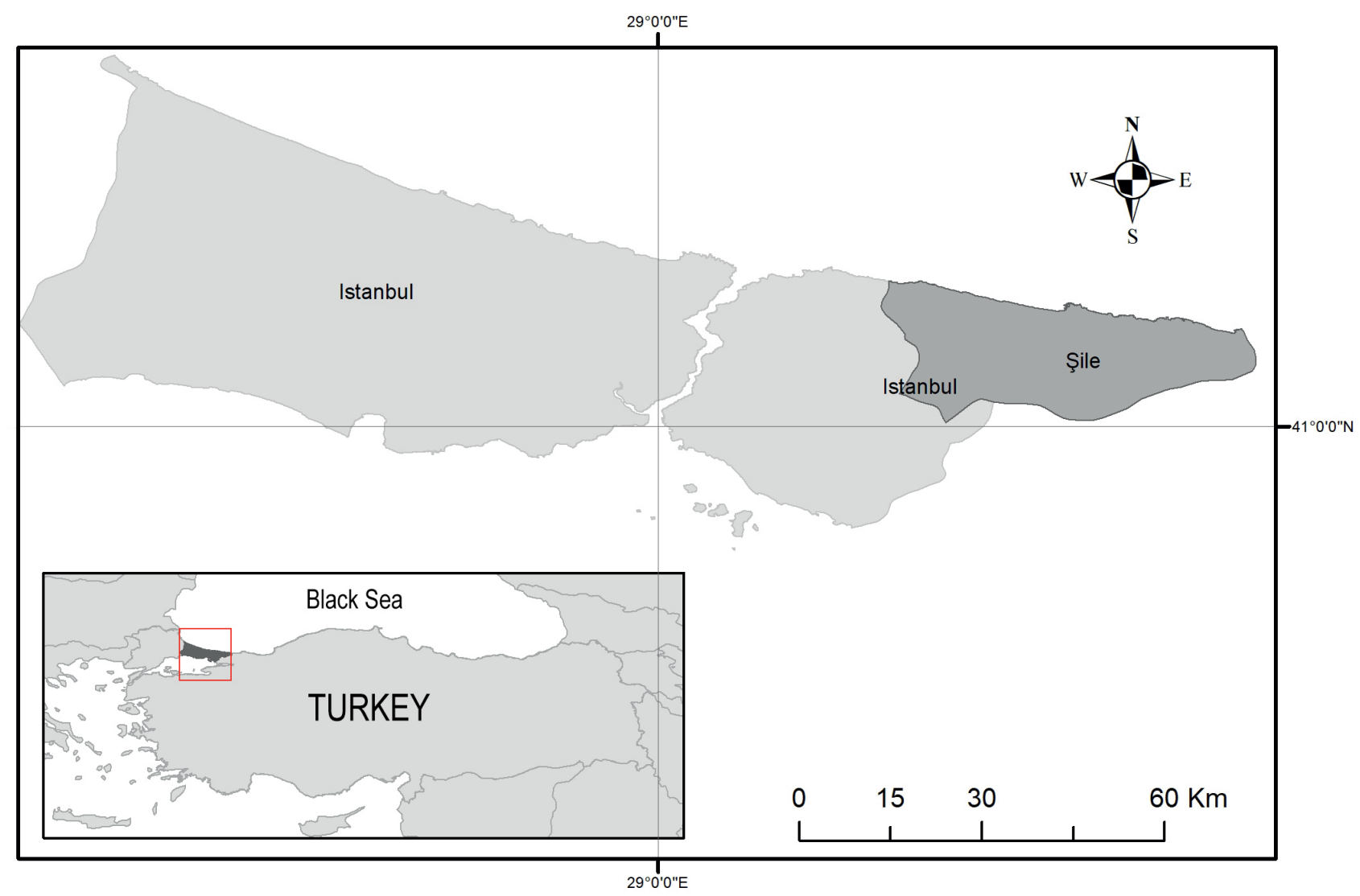

Fig. 1. Map of Şile province in which the study was performed. 
Table 1. Data for the identified parasites for each fish species.

\begin{tabular}{|c|c|c|c|c|c|c|c|c|}
\hline & Parasite Type & Host & $\mathrm{EFC}$ & IFC & $\mathrm{PCH}$ & $\mathrm{P} \%$ & Ml & MA \\
\hline \multirow{5}{*}{ 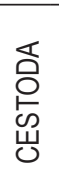 } & \multirow{5}{*}{ Progrillotia dasyatidis } & Chelidonichthys Iucerna & 2 & 2 & 4 & 100 & 2 & 2 \\
\hline & & Gaidropsarus mediterraneus & 19 & 11 & 28 & 58 & 2.6 & 1.47 \\
\hline & & Gobius niger & 32 & 11 & 29 & 34.4 & 2.6 & 0.9 \\
\hline & & Mullus surmuletus & 54 & 9 & 18 & 17 & 2 & 0.33 \\
\hline & & Scorpaena porcus & 46 & 2 & 2 & 4.3 & 1 & 0.04 \\
\hline \multirow{12}{*}{$\begin{array}{l}\text { 岕 } \\
\text { 峁 }\end{array}$} & \multirow{5}{*}{ Helicometra fasciata } & Caspialosa pontica & 32 & 7 & 12 & 22 & 1.7 & 0.4 \\
\hline & & Gobius niger & 32 & 3 & 7 & 9.4 & 2.3 & 0.2 \\
\hline & & Platichthys flesus & 1 & 1 & 41 & 100 & 41 & 41 \\
\hline & & Scorpaena porcus & 46 & 27 & 150 & 59 & 5.56 & 3.26 \\
\hline & & Solea vulgaris & 8 & 2 & 13 & 25 & 6.5 & 1.63 \\
\hline & \multirow{2}{*}{ Helicometra insolata } & Solea vulgaris & 8 & 1 & 10 & 12.5 & 10 & 1.25 \\
\hline & & Symphodus tinca & 1 & 1 & 4 & 100 & 4 & 4 \\
\hline & Anisocladium fallax & Uranoscopus scaber & 44 & 6 & 33 & 14 & 5.5 & 0.8 \\
\hline & Anisocladium gracile & Uranoscopus scaber & 44 & 16 & 42 & 36 & 2.6 & 1 \\
\hline & Anisocoelium capitellatum & Uranoscopus scaber & 44 & 18 & 73 & 41 & 4.1 & 1.7 \\
\hline & Prodistomum polonii & Trachurus mediterraneus & 68 & 6 & 12 & 9 & 0.18 & 0.18 \\
\hline & Monascus filiformis & Mullus surmuletus & 54 & 1 & 1 & 2 & 1 & 0.019 \\
\hline \multirow{22}{*}{$\begin{array}{l}\text { 亯 } \\
\text { 일 } \\
\text { 岸 }\end{array}$} & \multirow{16}{*}{ Hysterothylacium aduncum } & Caspialosa pontica & 32 & 23 & 180 & 72 & 8 & 5.4 \\
\hline & & Chelidonichthys Iucerna & 2 & 2 & 8 & 100 & 4 & 4 \\
\hline & & Engraulis encrasicolus & 33 & 17 & 115 & 52 & 7 & 4 \\
\hline & & Gaidropsarus mediterraneus & 19 & 10 & 103 & 53 & 10.3 & 5.4 \\
\hline & & Gobius niger & 32 & 25 & 268 & 78.1 & 11 & 8.4 \\
\hline & & Merlangius merlangus euxinus & 107 & 79 & 922 & 74 & 12 & 9 \\
\hline & & Mullus surmuletus & 54 & 13 & 23 & 24 & 1.8 & 0.43 \\
\hline & & Sarda sarda & 6 & 3 & 27 & 50 & 9 & 4.5 \\
\hline & & Sciaena umbra & 2 & 1 & 3 & 50 & 3 & 1.5 \\
\hline & & Scorpaena porcus & 46 & 19 & 115 & 41.3 & 6.05 & 2.5 \\
\hline & & Solea vulgaris & 8 & 2 & 57 & 25 & 28.5 & 7.1 \\
\hline & & Spicara smaris & 32 & 25 & 369 & 78.1 & 14.8 & 11.5 \\
\hline & & Symphodus tinca & 1 & 1 & 2 & 100 & 2 & 2 \\
\hline & & Trachinus draco & 11 & 10 & 30 & 91 & 3 & 2.3 \\
\hline & & Trachurus mediterraneus & 68 & 49 & 631 & 72.1 & 13 & 9.3 \\
\hline & & Uranoscopus scaber & 44 & 28 & 369 & 64 & 13.2 & 8.4 \\
\hline & \multirow{2}{*}{ Philometra sp. } & Trachinus draco & 11 & 1 & 8 & 9.1 & 8 & 0.73 \\
\hline & & Trachurus mediterraneus & 68 & 1 & 4 & 1.5 & 4 & 0.06 \\
\hline & \multirow{2}{*}{ Cucullanellus minutus } & Solea vulgaris & 8 & 2 & 10 & 25 & 29 & 7.1 \\
\hline & & Symphodus tinca & 1 & 1 & 13 & 100 & 13 & 13 \\
\hline & \multirow{2}{*}{ Capillaria gracilis } & Gobius niger & 32 & 2 & 13 & 6.3 & 7 & 0.4 \\
\hline & & Mullus surmuletus & 54 & 1 & 18 & 1.9 & 18 & 0.33 \\
\hline \multirow{5}{*}{ 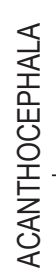 } & \multirow{3}{*}{ Acanthocephaloides irregularis } & Gaidropsarus mediterraneus & 19 & 1 & 5 & 5.3 & 5 & 0.26 \\
\hline & & Gobius niger & 32 & 3 & 9 & 9.4 & 3 & 0.28 \\
\hline & & Scorpaena porcus & 46 & 9 & 23 & 20 & 2.56 & 0.5 \\
\hline & Neoechinorhynchus agilis & Liza aurata & 9 & 4 & 6 & 44 & 1.5 & 0.6 \\
\hline & Solearhynchus kostylewi & Solea vulgaris & 8 & 1 & 3 & 12.5 & 3 & 0.38 \\
\hline
\end{tabular}

EFC: Evaluated Fish Count, IFC: Infected Fish Count, PCH: Parasite Count in Host, P: Prevalence, MI: Mean Intensity, MA: Mean Abundance 
Schell (1970), Fagerholm (1982), Khalil et al. (1994), Gibson et al. (2002), Jones et al. (2005), Yamaguthi (1955a), Yamaguthi (1955b), Yamaguthi (1955c). The prevalence, mean intensity, and mean abundance values for all parasite species were calculated as suggested by Bush et al. (1997).

\section{Ethical Approval and/or Informed Consent}

For this study formal consent is not required.

\section{Results}

As the endohelminths of a total of 508 fish belonging to 19 different species were inspected as part of the study, 15 different helminth species were encountered. 357 out of the 508 fish inspected $(70.27 \%)$ were found to be infected with parasites, and a total of 3813 parasites were detected amongst all the fish. 313 of the fish $(61.6 \%)$ were found to be infected with nematodes, 75 (14.76\%) were infected with Digeneans, 35 (6.88 \%) were infected with Cestoda and $18(3.54 \%)$ were infected with Acanthocephala group of parasites. A total of 3288 Nematodes, 398 Digeneans, 81 Cestodes, and 46 Acanthocephalans were determined throughout the specimens (Table 1).

The only Cestoda encountered as part of the study was the Progrillotia dasyatidis, which belongs to the Progrillotiidae family. The species identified for the Digenean group are as follows: Helicometra fasciata and Helicometra insolata species belonging to the Opecoelidae family, Anisocladium fallax, Anisocladium gracile, and Anisocoelium capitellatum belonging to the Acanthostomidae family, Prodistomum polonii of the Lepocreadiidae family, and Monascus filiformis of the Fellodistomidae family. As for nematodes, the species identified consisted of Hysterothylacium aduncum of the Anisakidae family, Philometra sp. of the Philometridae family, Cucullanellus minutus of the Cucullanidae family, and Capillaria gracilis of the Capillaridae family. Finally, the species identified for the Acanhocephala consisted of Acanthocephaloides irregularis of the Arhythmacanthidae family, Neoechinorhynchus agilis of the Neoechinorhynchidae family, and Solearhynchus kostylewi of the Echinorhynchidae family (Table 1). Amongst these, Capillaria gracilis was identified for the first time in Turkey as part of the present study (Fig. 2).

Considering the relationship with the inspected fish species and corresponding parasite species, the highest number of species of parasites was found in Gobius niger and Solea vulgaris fish species, each of which were infected with 5 different types of parasites. Scorpaena porcus, Mullus surmuletus, and Uranoscopus scaber were infected with four different species of parasites, Gaidropsarus mediterraneus, Symphodus tinca, and Trachurus mediterraneus were infected with three different species of parasites, Caspialosa pontica, Chelidonichthys lucerna, and Trachinus draco were infected with two different species of parasites, and Engraulis encrasicolus, Liza aurata, Merlangius merlangus euxinus, Platichthys flesus, Sarda sarda, Sciaena umbra, and Spicara smaris were found to be infected with only one type of parasite. The highest prevalence for the parasite species encountered as part of this study was that of $\mathrm{H}$. aduncum with $84.5 \%$. H. aduncum was also the parasite species that infected the highest number of different species of fish (16 species). P. dasyatidis and $H$. fasciata share the second most prevalent distribution with $26.3 \%$. A. fallax, A. gracile, A. capitellatum, M. filiformis, P. polonii, N. agilis and S. kostylewi each share $5.3 \%$ prevalence and they were each encountered only in a single species of fish.

\section{Discussion}

Until 2005, a total of 114 parasitic helminths (87 Platyhelminthes, 16 Nemathelminthes, 9 Acanthocephala, 2 Annelida) were reported in the first checklist that could be considered a report for the marine fish of Turkey, recorded as observed from 65 marine fish (Öktener, 2005). Various other researchers (Oğuz, 1996; Keser,

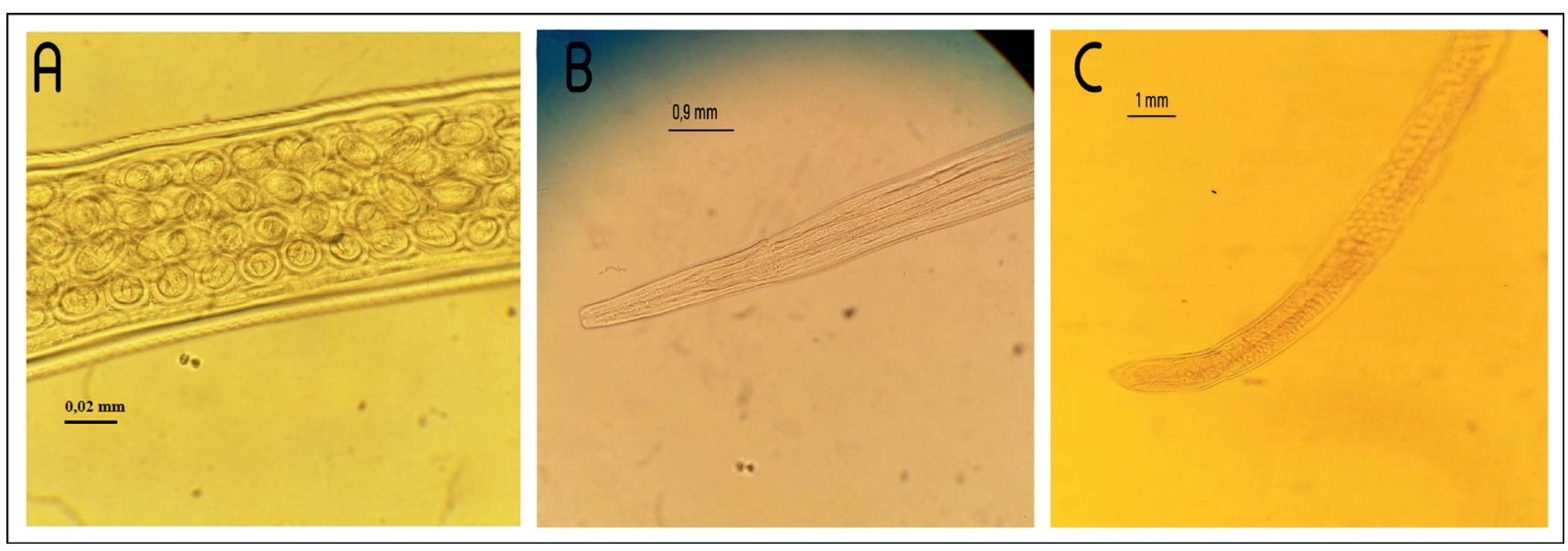

Fig. 2. Capillaria gracilis.

A: eggs, B: Anterior, C: Posterior (o) 
2002; Tuncel, 2003; Oguz \& Bray, 2006; Oğuz \& Kvach, 2006; Keser et al., 2007; Oguz \& Bray, 2008; Akmirza, 2012; Tepe \& Oguz, 2013; Tepe et al., 2014) have also performed different studies for the parasite fauna of the marine fish of Turkey.

For the Cestoda, the Progrillotia dasyatidis species of the Progrillotiidae family was first determined for the seas surrounding Turkey in a Gobius niger (Oguz \& Bray, 2008), and was later reported to be present in Gobius niger, Uranoscopus scaber, Gaidropsarus mediterraneus, Ophidion rochei and Mullus barbatus (Tepe et al., 2014). In the present study, the only species encountered for the Progrillotiidae family was Progrillotia dasyatidis, which was identified in Gobius niger, Mullus surmuletus, Gaidropsarus mediterraneus, Chelidonichthys lucerne, and Scorpaena porcus fish species.

Helicometra fasciata is known to have a high host infection spread and was reported first for Turkey in the Sea of Marmara Gaidropsarus mediterraneus, Gobius cobitis, Scorpena scrofa, Symphodus tinca, Trachurus trachurus, and Zosterisessor ophiocephalus fish species caught from the shores of Mudanya (Oğuz, 1995; Oguz \& Bray, 2006). It was also reported for Pagellus erythrinus, Scorpaena porcus, Conger conger, and Trigla lucerna species caught in the Aegean Sea (Akmirza, 2000, 2001), Conger conger fish of the Gökçeada shores (Akmirza, 2012), and in the intestines of Scorpaena porcus fish species caught from the Eastern Black Sea shores (Tepe \& Oguz, 2013; Tepe et al., 2014). In the present study, Helicometra fasciata were encountered in CaspiaIosa pontica, Gobius niger, Platichthys flesus, Scorpaena porcus, and Solea vulgaris fish. The highest infection rate for this species was determined for Platichthys flesus (100\%). Another species of the Helicometra genus, Helicometra insolata, is of Atlantic origin, and this species was previously encountered in Turkey in the Marmara Sea along the shorelines of Mudanya, in Symphodus tinca (Oğuz, 1995). In the present study, this species was determined in Symphodus tinca and Solea vulgaris, and the mean intensity was found to be highest in Solea vulgaris with a value of 10 .

Anisocladium fallax is the endoparasite of the Uranoscopus scaber fish, and was previously reported to be present in the Mudanya shores of the Sea of Marmara (Oğuz, 1995; Oguz \& Bray, 2006), in the Gökçeada Island shores of the Aegean Sea (Akmirza, 2013), and the Eastern Black Sea shores (Tepe, 2011; Tepe et al., 2014). In the present study, a total of 44 Uranoscopus scaber fish were inspected, and 6 of them were found to be infected with Anisocladium fallax. The infection rate was $14 \%$, and the mean intensity was determined as 5.5 .

In Turkey, Anisocladium gracile was before determined in the intestines of Uranoscopus scaber (Tepe, 2011; Tepe et al., 2014). The parasite was also reportedly present in the digestive tract of the same host in the Western Mediterranean Sea (Bartoli \& Gibson, 2000; Bartoli et al., 2005). The prevalence of this parasite in the Uranoscopus scaber caught in the Marseille shores of the Western Mediterranean Sea was reported as $72.7 \%$, and as $100 \%$ in fish from the Corsican shores. The mean intensity for Marseilles and
Corsica fish were reported as 15.5 and 11, respectively (Bartoli \& Gibson, 2000). In the present study, the prevalence of the parasite in Uranoscopus scaber was determined as $36 \%$, while the mean intensity was found to be 2,6 .

Anisocoelium capitellatum is a parasite that infects the gall bladder of Uranoscopus scaber and was detected in Turkey the first time in the Marmara Sea, around the shores of Mudanya by Oğuz (1995). Tepe (2011) and Tepe et al. (2014) have also reported the parasite to be present around the shores of the Eastern Black Sea. In the present study which focused on the shorelines of Şile, 18 out of the 44 Uranoscopus scabers inspected were found to contain the parasite (41\%), and the mean intensity was determined as 4.1 .

Prodistomum polonii which was previously only encountered in the intestines of Trachurus mediterraneus', was reportedly present in the Trachurus trachurus of the Dardanelle Strait of Turkey by Keser et al. (2007). In the present study, this species was found to have a prevalence of $9 \%$, and mean intensity and abundance of 0.18 .

Another Digenean species, Monascus filiformis, has previously been reported in Turkey in the shores of Mudanya, infecting the Symphodus tinca fish (Oguz \& Bray, 2006). This species of parasites was also reported for the Trachurus trachurus of the Sea of Marmara (Keser et al., 2007). In the present study, Monascus filiformis was encountered only in a single fish ( $2 \%$ prevalence) of Mullus surmuletus.

Hysterothylacium aduncum was first encountered in Turkey in Trachurus mediterraneus and Engraulis encrasicholus and Sprattus sprattus (Öktener, 2005). Doğanay (1994) and Ismen \& Bingel (1999) have reported the parasite in Merlangius merlangus of the Turkish coasts of the Black Sea. Furthermore, some of the anchovies obtained from the fish market of Eskişehir was reported to be infected with Contracaecum sp. (Yetim, 1985). The parasite was also encountered in Merluccius merluccius, Gobius niger, and Trachurus trachurus caught in the Sea of Marmara (Oğuz, 1995; Keser et al., 2007), in Scomber japonicas of the Aegean Sea (Akmirza, 1997), in the Trachurus trachurus obtained from Erzurum fish market (Özkan et al., 2010), and later in Pagellus erythrinus and Lophius piscatorius caught nearby the Gökçeada Island (Akmirza, 2013). In this study, H. aduncum was determined to be present with a very high prevalence $(84.5 \%)$, and was found to have infected Caspialosa pontica, Chelidonichthys lucerna, Engraulis encrasicolus, Gaidropsarus mediterraneus, Gobius niger, Merlangius merlangus euxinus, Mullus surmuletus, Sarda sarda, Sciaena umbra, Scorpaena porcus, Solea vulgaris, Spicara smaris, Symphodus tinca, Trachinus draco, Trachurus mediterraneus, and Uranoscopus scaber. The mean intensity of the parasite was the highest in Solea vulgaris with 28.5, and the mean abundance was the highest in Spicara smaris 11.5.

In Turkey, Epinephelus gigas, E. aeneus, E. marginatus, E. costae, and Mycteroperca rubra were reported to be infected with Philometra sp. Furthermore, Epinephelus marginatus and Mycteroperca rubra were reported to contain Philometra lateolabracis, 
while some Pagellus erythrinus were reported to be infected with Philometra filiformis (Öktener, 2005). In the Eastern Black Sea, Uranoscopus scaber and Trachurus mediterraneus were reportedly infected with Philometra globiceps (Tepe, 2011; Tepe \& Oguz, 2013). In the present study, the Philometra sp. was found to be present in Trachinus draco and Trachurus mediterraneus, and the infection prevalence of the parasite was found to be the highest in Trachinus draco with $9.1 \%$

Another nematode species, Cucullanellus minutus, was first reported in Turkey in the Ekinli Lagoon of the Marmara, in Pleuronectes flesus by Oğuz (1989). In our study, Cucullanellus minutus was found to have infected two Solea vulgaris and one Symphodus tinca.

There is some information in the literature that Capillaria sp. was determined in angelfish (Pterophyllum scalare) (Ürkü \& Yardimci, 2013). While the Capillaria genus displays a widespread on the fish of Turkey, it is mostly encountered in aquarium and freshwater fish. Doğanay et al. (1989) reported it first for the aquarium fish, while it was reported from the freshwater fish for the first time by Türkmen (1990) in Rutilus frisii from the Iznik Lake. Later, the Capillaria sp. was identified in the Mullus surmuletus of the Aegean Sea (Akmirza, 2000), while Pseudocapillaria tomentosa was identified within the intestines of Cyprinus carpio of the Manyas (Bird) Lake (Öztürk, 2000). Capillaria sp. was also encountered in the Aphanius danfordii of the Sarıkum Lagoon of the Sinop province (Öztürk \& Özer, 2008). In this study, Capillaria gracilis species was encountered in two Mullus surmuletus and a single Gobius niger. Still, it was the most prevalent in Gobius niger with $6.3 \%$. Since this species was never reported for the marine or inland seas of Turkey, this study is the first to report its presence for theTurkey marine.

Acanthocephaloides irregularis of the Acanthocephala group of parasites was first reported from the Sukhyi Lyman Ukrainian shores and the Bay of Odesa, in Parablennius zvonimiri, Ponticola eurycephalus, Proterorhinus marmoratus and Syngnathus abaster fish (Amin et al., 2011). The first recording of the parasite group for Turkey was for the Scorpaena porcus of the Black Sea shores with Acanthocephaloides propinquus infection (Tepe, 2011), which was later revised as Acanthocephaloides irregularis (Tepe \& Oguz, 2013). Acanthocephaloides irregularis was found to be present in Scorpaena porcus, Gaidropsarus mediterraneus, and Gobius niger fish in this study as well. The highest prevalence of infection was in Scorpaena porcus with $20 \%$.

Neoechinorhynchus agilis was first encountered in Mugil cephalus (Cleave, 1921). In Turkey, this species was reported to be infecting the Mugil cephalus, Liza aurata, Liza saliens, Liza ramada and Chelon labrosus of the Aegean Sea (Altunel, 1982), in Liza saliens of the Dardanelle Strait (Keser et al., 2007), and Liza aurata of the Eastern Black Sea (Tepe \& Oguz, 2013). In our study, Neoechinorhynchus agilis was only determined in the Liza aurata species of fish with $44 \%$ infection prevalence.

Another Acanthocephala species, Solearhynchus kostylewi, was first reported in Turkey from the Mudanya shores of the Marmara Sea as Acanthocephaloides soleae (Oğuz, 1995), which was later revised as Paracanthocephaloides kostylewi (Oğuz \& Kvach, 2006). The same parasite was later identified as Solearhynchus kostylewi (Kvach \& Oğuz, 2010). In research performed in the Black Sea, Acanthocephaloides kostylewi was reported as the specific parasite of Solea nasutus (Belofastova, 2004). In our study, Solearhynchus kostylewi was only found to be present in Solea vulgaris with $12.5 \%$ infection prevalence.

Among the reasons for the differences observed in the present study the location where the fish are caught, pollution rate of water, host and intermediate host population, seasonal variations, and methods used can be included.

We hope that this study performed to determine the endohelminth fauna of the fish of the Şile shores of Turkey will present valuable reference opportunities for future studies and will contribute to the insight regarding the diversity of endohelminth of teleost fish of Turkey.

\section{Conflicts of Interest}

Authors state no conflict of interest.

\section{Acknowledgment}

The study has been poster presented in the $19^{\text {th }}$ National Parasitology Congress with international participation Echinococcosis Symposium, 5 - 9 October 2015, Erzurum, Turkey. This study was prepared from a Ph.D. thesis entitled "Endohelminth Fauna of Teleost Fishes from Coasts of Şile" and supported by the Scientific Research Project Directory of the Atatürk University (grant number 2011/101).

\section{References}

Adams, A., Murrell, K., Cross, J. (1997): Parasites of fish and risks to public health. Rev. sci. tech. off. int. Epiz, 16 (2): 652 - 660

AkMIRZA, A. (1997): Kolyoz (Scomber japonicus Houttuyn, 1786) balığının parazit faunasından örnekler [The parasites of chub mackerel (Scomber japonicus Houttuyn, 1786)]. EÜ Su Ürünleri Dergisi, 14 (1-2): 173 - 181 (In Turkish)

AkmiRZA, A. (2000): Gökçeada civarındaki Sparidae familyasına ait balıklarda rastlanılan parazitlerin mevsimel dağııımı [Seasonal distribution of parasites detected in fish belonging to the Sparidae family found near Gökçeada]. Turkiye Parazitol Derg, 24: 435 - 441 (In Turkish)

AkmiRzA, A. (2001): İstavrit balığında (Trachurus trachurus Linnaeus, 1758) rastlanılan parazitlerdeki mevsimsel değişimler [Seasonal variations in the parasites of horse mackerel (Trachurus trachurus (Linnaeus, 1758)]. EÜ Su Ürünleri Dergisi, 18 (1-2): $33-37$ (In Turkish) 
AkmiRzA, A. (2012): Metazoan parasite fauna of conger Eel (Conger conger L.) near Gökçeada, northeastern Aegean Sea, Turkey. Kafkas Univ Vet Fak Derg, 18: 845 - 848. DOI: 10.9775/ kvfd.2012.6624

AkMıRZA, A. (2013): Gökçeada kıyı sularındaki balıkların parazitik nematodları [Parasitic nematodes of fish in the coastal waters of Gökçeada]. T Parazitol Derg, 37: 199 - 202. DOI: 10.5152/ tpd.2013.44 (In Turkish)

Altunel, F. (1982). Seasonal Changes and Trematodes in Mullet caught from the Aegean Sea. (Assistant Professors Thesis), UIudag University, Bursa

Amin, O.M., OĞuz, M.C., Heckmann, R.A., Tepe, Y., Kvach, Y. (2011): Acanthocephaloides irregularis n. sp. (Acanthocephala: Arhythmacanthidae) from marine fishes off the Ukrainian Black Sea coast. Syst Parasitol, 80 (2): 125. DOI: 10.1007/s11230-011-93120

Bartoli, P., Bray, R.A., Gibson, D.I. (2005): Three poorly known and rarely reported bucephalid species (Digenea) in fishes from the Western Mediterranean. Syst Parasitol, 62 (2): 135 - 149. DOI: 10.1007/s11230-005-5489-4

Bartol, P., Gibson, D.I. (2000): Three little known acanthostomine digeneans from Uranoscopus scaber $\mathrm{L}$. in the western Mediterranean. Syst Parasitol, 46 (2): 123 - 141. DOI: 10.1023/a:1006375224597

BAYLIS, H. (1922): Notes on the collection and preservation of parasitic worms. Parasitology, 14 (3-4): 402 - 408. DOI: 10.1017/ S0031182000010301

Belofastova, I. (2004): About taxonomic status of some acanthocephalan species of the Black Sea fishes. Vestn Zool, 38 (5): 11 - 18 Bush, A.O., LafferTy, K.D., LotZ, J.M., SHostak, A.W. (1997): Parasitology meets ecology on its own terms: Margolis et al. revisited. J Parasitol, 83: 575 - 583. DOI: 10.2307/3284227

Bylund, G., Fagerholm, H., Calenius, G., Wikgren, B., Wikstrom, M. (1980): Parasites of fish in Finland. II. Methods for studying parasite fauna in fish. Acta Acad. Åbo. Ser. B, 40 (2): 1 - 23

CABLE, R.M. (1976). An illustrated laboratory manual of parasitology. Minneapolis: Publishig Company

CAN, A., BılecenoğLu, M. (2005): Türkiye Denizlerinin Dip Balıkları Atlası [Bottom Fish Atlas of Turkish Sea]. Ankara: Arkadaş Yayınevi (In Turkish)

Cleave, V. (1921): Acanthocephala from the Eel. Transactions of the American Microscopical Society, 40 (1): 1 - 13. DOI: $10.2307 / 3221949$.

DAwEs, B. (1947). The trematoda of British fishes. UK: The Royal Society of London

DEMIRTAŞ, M. (2011): Terkos Gölü'nde Yaşayan Kadife Balıklarının (Tinca tinca L. 1758) Helmint Parazitlerinin Mevsimsel Dağılımı ve Etkileri [The Seasonal Distribution and Effect of Tench Fish (Tinca tinca L., 1758) Helminthes Parasites Living in Terkos Lake]. Turkiye Parazitol Derg, 35: 159 - 163. DOI:10.5152/tpd.2011.40 (In Turkish)

DoĞAnAY, A. (1994): Karadenaiz'den avlanan mezgit balıklarında
Hysterothylacium aduncum (Rudolphi, 1802) olgusu [A record of Hysterothylacium aduncum (Rudolphi, 1802) in cod-fish (Gadus sp.) from Black Sea]. A.Ü.Vet.Fak.Derg., 41 (2): 208 - 217 (In Turkish)

DoĞanay, A., Bozan, H., ÖGE, S. (1989): Ankara'da bazı akvaryum balıklarında görülen parazitler [Parasitological examination of some aquarium fishes in Ankara]. Ankara Üniv Vet Fak Derg, 36 (2): 795 - 806 (In Turkish)

FAgerHolm, H. (1982): Parasites of fish in Finland. VI. Nematodes. Acta Acad. Åbo. Ser. B: 40(6): 1 - 128

FISCHTHAL, J. (1980): Some digenetic trematodes of marine fishes from Israel's Mediterranean coast and their zoogeography, especially those from Red Sea immigrant fishes. Zool Scr, 9 (1-4): $11-23$

GELDIAY, R. (1969): İmir Körfezi'nin başlıca balıkları ve muhtemel invasionları [Important Fishes Found in the Bay of Izmir and Their Possible Invasions]. İzmir: Ege Üniversitesi Fen Fakültesi Monografileri (In Turkish)

GiBson, D., Jones, A., Bray, R. (2002). Keys To the Trematoda (Vol. 1). UK: $C A B$ International

GÜnGÖR, E., ÇAĞATAY, M. (2010): Karadeniz'de son 3000 yıldaki ani çevresel değişimler [Rapid changes in the ecological conditions of the Black Sea over the last 3 kyr]. ITÜ Dergisi, 5 (4): 23 - 33 (In Turkish)

ISMen, A., Bingel, F. (1999): Nematode infection in the whiting Merlangius merlangus euxinus off Turkish Coast of the Black Sea. Fish Res, 42 (1-2): 183 - 189. DOI: 10.1016/S0165-7836(99)00022-3 Jones, A., Bray, R., Gibson, D. (2005). Keys to Trematoda. (Vol. 2, pp. 74): CAB International

KeSER, R. (2002): Çanakkale Kıyıları'ndaki Bazı Teleost Balıkların Sindirim Sisteminde Rastlanan Helmintler [Parasites found in digestive systems of some teleost fishes caught in Çanakkale shores]. (MSc), Çanakkale Onsekiz Mart University, Çanakkale, Turkey (In Turkish)

Keser, R., Bray, R., Oguz, M., Çelen, S., Erdoğan, S., Doğuturk, S., AkLANoǦlu, G., Martı, B. (2007): Helminth parasites of digestive tract of some teleost fish caught in the Dardanelles at Canakkale, Turkey. Helminthologia, 44 (4): 217 - 221. DOI: 10.2478/s11687007-0035-3

Khall, L., Jones, A., Bray, R. (1994). Keys to the Cestode parasites of vertebrates. UK: International Institue of Parasitology KvacH, Y., OĞUz, M. (2010): Solearhynchus kostylewi (Meyer, 1932) comb. nov. (Acanthocephala: Echinorhynchidae), a rare parasite of Solea solea (Pisces: Soleidae) in the Gemlik Bay, Sea of Marmara. Parasite, 17 (1): 47 - 51. DOI: 10.1051/parasite/2010171047 Oguz, M., Bray, R. (2006): Digenetic trematodes of some teleost fish off the Mudanya Coast (Sea of Marmara, Turkey). Helminthologia, 43 (3): 161 - 167. DOI: 10.2478/s11687-006-0030-0

Oguz, M., Bray, R. (2008): Cestoda and Monogenea of some teleost fishes off the Mudanya Coast (Sea of Marmara, Turkey). Helminthologia, 45 (4): 192 - 195. DOI: 10.2478/s11687-008-0038-8 OĞUz, M. (1989): Ekinli Lagünü’ndeki pisi balıklarının (Pleuronect- 
es flesus luscus L.) parazit faunası [Parasite fauna of flounder (pleuronectes flesus luscus L. 1758) in Ekinli lagoon]. (MSc), UIudag University, Bursa (In Turkish)

OĞuz, M. (1995): Mudanya kıyılarındaki bazı teleost balıklarda rastlanilan helmintler [Helminths encountered in some teleost fishes in Mudanya coast]. (PhD), Uludağ University, Bursa (In Turkish)

OĞuz, M. (1996): Mudanya kıyılarında yakalanan bazı teleost balıklarda kayıt edilen nematodlar [Nematodes recorded in some teleost fishes caught by Mudanya coast]. Turkiye Parazitol Derg, 20 (3-4): 467 - 477 (In Turkish)

OĞUz, M., Kvach, Y. (2006): Occurrence of acanthocephalans in teleost fishes of Gemlik Bay, Sea of Marmara, Turkey. Helminthologia, 43 (2): 103 - 108. DOI: 10.2478/s11687-006-0020-2

ÖKTENER, A. (2005): A checklist of parasitic helminths reported from sixty-five species of marine fish from Turkey including two new records of monogeneans. Zootaxa, 1063 (1): 33 - 52. DOI: 10.11646/zootaxa.1063.1.2

ÖZAN, S.T., KıR, İ. (2005): Kovada Gölü havuz balığı (Carassius carassius L., 1758)'nın parazitleri üzerine bir çalışma [An Investigation of Parasites of Goldfish (Carassius carassius L., 1758) in Kovada Lake]. T Parazitol Derg, 29 (3): 200 - 203 (In Turkish)

ÖzKan, Y., AkSAKAL, E., OĞuz, M.C. (2010): İstavrit (Trachurus trachurus, L. 1758) Balı̆ı̆ında Kaydedilen Nematod Larvalarının Balık Boy Gruplarına Göre Karşılaştırmalı Yaygınlık, Ortalama Yoğunluk ve Bolluk Parametrelerinin Belirlenmesi [The Determination of Comparative Prevalence, Mean Intensity and Abundance according to Fish Size Parameters of Recorded Nematode Larvae of Horse Mackerel (Trachurus trachurus, L. 1758)]. Res. J. Biol. Sci., 3 (1): 145 - 147 (In Turkish)

Öztürk, T., Özer, A. (2008): Sarıkum Lagününde (Sinop) Bulunan ve Endemik Bir Tür Olan dişlisazancık Aphanius danfordii (Boulenger, 1890) (Osteichthyes: Cyprinodontidae) Balı̆ının Parazit Faunası [Parasitic fauna of the toothcarp Aphanius danfordii (Boulenger, 1890) (Osteichthyes: Cyprinodontidae), an endemic fish from Sarıkum Lagoon Lake in Sinop (Turkey)]. J Fish Sci, 2 (3): 388 - 402 (In Turkish)

ÖzTÜRK, M. (2000): Manyas (Kuş) Gölü balıklarının helmint faunası [Helminth fauna of Manyas (Kuş) lake]. (PhD), Uludag University, Bursa (In Turkish)

ÖztüRK, M. (2005): Eber Gölü (Afyon)'ndeki sazan (Cyprinus carpio L.)'ların metazoon parazitleri üzerine bir araştırma [An Investigation of Metazoan Parasites of Common Carp (Cyprinus carpio L.) in Lake Eber, Afyon, Turkey]. Turkiye Parazitol Derg, 29 (3): $204-210$ (In Turkish)

Pantin, F. (1960). Notes On Microscopical Techique For Zoologists. UK: Cambrige University Press

PRITCHARD, M.H., KRUSE, G.O. (1982). The collection and preservation of animal parasites. Lincoln, Nebraska: University of Nebraska Press

Schell, S. (1970). How To Know The Trematodes. Dubuque, lowa: Wm. C. Brown Company Publishers
SLASTENENKo, E. (1955): Karadeniz Havzası Balıkları [The fishes of the Black Sea Basin]. İstanbul: Et Balık Kurumu Umum Müdürlüğü Yayınları [Meat and Fish Authority Publications] (In Turkish)

TAşçı, S., Topçu, A. (1990): Balıklardan insanlara geçebilen (zoonoz) parazitler, biyolojileri ve meydana getirdiği hastalıklar [Parasites that can be transmitted from fish to humans (zoonosis), their biology and diseases]. YYU Vet Fak Derg, 1 (1): 126 - 140 (In Turkish)

TEPE, Y. (2011): Trabzon, Rize ve Artvin kıyllarından yakalanan bazı ekonomik öneme sahip teleost balıklarının endohelmint faunası [Endohelminth fauna of some ecomonically important teleost fishes from coasts of Trabzon, Rize and Artvin]. (Ph.d), Erzurum University, Erzurum (In Turkish)

Tepe, Y., Oguz, M. (2013): Nematode and acanthocephalan parasites of marine fish of the eastern Black Sea coasts of Turkey. Turk Zool Derg, 37 (6): 753 - 760. DOI: 10.3906/zoo-1206-18

Tepe, Y., Oguz, M., Heckmann, R. (2014): Digenean and cestode parasites of teleost fish from the Eastern Black Sea Region. Turk Zool Derg, 38 (2): 209 - 215. DOI: 10.3906/zoo-1205-5

TunCEL, V. (2003): Karadeniz ve Marmara'da avlanan hamsi (Engraulis ecrasicholus (Linneaeus, 1758)) balığının parazit faunasının karşılaştıııması The Comparison of parasite fauna of anchovy (Engraulis encrasicolus (Linnaeus, 1758)) fished in the Black Sea and the Marmara sea]. (MSc), İstanbul University, Istanbul (In Turkish)

TuRgut, E., ÖzGüL, G. (2009): Sucul ekosistemin izlenmesinde kirlilik biyoindikatörü olarak balık parazitlerinin kullanılması [The Use of Fish Parasites as Pollution Bioindicator in Monitoring Aquatic Ecosystem]. GOÜ. Ziraat Fak Derg, 26 (1): 13 - 18 (In Turkish) Türkmen, H. (1990): Iznik Gölü'ndeki sazan (Cyprinus Carpio Linneus, 1758) ve akbalıkların Rutilus frisii (Nordman, 1840) sindirim kanalı helmintleri [Helminths of the digestive tract of the carps (Cyprinus Carpio L.) and the roachs (Rutilus frisii)]. (PhD), Istanbul University, Istanbul (In Turkish)

ÜRKÜ, Ç., YARDIMCI, R.E. (2013): Melek baliklarinda (Pterophyllum scalare) Capilaria sp. enfestasyonu ve bakteriyel septisemi [Capillaria sp. Infestation and Bacterial Septicemia in the Angel Fish (Pterophyllum scalare)]. J Fishscicom, 7 (3): 232. DOI: 10.3153/ jfscom.2013024 (In Turkish)

WARDLE, R.A. (1932): On the technique of cestode study. Parasitology, 24 (2): 241 - 252. DOI: 10.1017/S0031182000020606.

YamaguthI, S. (1955a). Systema Helminthum, (Acanthocephala)) (Vol. USA): John Wilely.

Yamaguthl, S. (1955b). Systema Helminthum, (Digenea) USA: John Wilely.

Yamaguthl, S. (1955c). Systema Helminthum, (Nematoda) (Vol. USA): John Wilely.

YETIM, M. (1985). Eskişehir'de tüketilen balıklarda görülen parazitler. (MSc), Anadolu University, Eskişehir. (in Turkish).

YoRke, W., Maplestone, P. (1962). The Nematode Parasites of vertebrates. New York: Hafner Publishing Company. 